Proceeding ICOGISS 2019

Page 221-231, ISBN: 978-602-6 988-75-1

Web Jurnal Online: jurnal.unmuhjember.ac.id By: Santosa; Hikmah Muhaimin; Ahmad Hasan Afandi

Implementation of Selection and Recruitment on the Performance of Bicak Village Devices

in Trowualan District, Mojokerto Regency

\title{
IMPLEMENTATION OF SELECTION AND RECRUITMENT ON THE PERFORMANCE OF BICAK VILLAGE DEVICES IN TROWUALAN DISTRICT, MOJOKERTO REGENCY
}

\author{
Santosa, Hikmah Muhaimin, Ahmad Hasan Afandi \\ Universitas Islam Majapahit \\ hikmahmuhaimin@gmail.com
}

\begin{abstract}
The Recruitment Process is defined as the process of withdrawing a number of employees who have the potential to be selected as employees or employees. Selection is the selection process of a group of applicants who best meet the criteria for positions available within the village. Job training is a learning process that involves acquiring expertise, concepts, regulations, or attitudes to improve employee performance. This study aims to determine whether the process of recruitment, selection, and job training has an influence and implementation on the performance of Bicak village devices. Type of associative research using multiple linear regression analysis techniques. The results of the study show that the recruitment, selection and job training processes simultaneously have a significant effect on device performance. The recruitment process is the most dominant factor affecting the performance of the device. The village should improve and pay attention to the recruitment process so that it can improve the performance of the equipment so that villages can get competent and reliable employees based on the classification at the village office.
\end{abstract}

Keywords: the process of recruitment, selection, job training, employee performance. 
Proceeding ICOGISS 2019

Page 221-231, ISBN: 978-602-6 988-75-1

Web Jurnal Online: jurnal.unmuhjember.ac.id

By: Santosa; Hikmah Muhaimin; Ahmad Hasan Afandi

Implementation of Selection and Recruitment on the Performance of Bicak Village Devices in Trowualan District, Mojokerto Regency

\section{INTRODUCTION}

Management of Human Resources (HR) is an important thing in achieving goals. Generally village leaders expect good performance from each employee in carrying out the tasks assigned by the village. The village head realizes that Human Resources (HR) are the basic capital in the development process and community service, therefore the quality of human resources must always be developed and directed towards achieving the goals set by the village. The activities of human resource governance consist of: human resource planning, procurement, direction, development, maintenance, and dismissal. This is intended so that the village government can manage good human resources effectively and efficiently.

One of the activities in HR management is recruitment and selection. Recruitment is a process of collecting a number of applicants who have qualifications that are in accordance with what the village needs, to be employed in the village (Malthis, 2001). The benefits of recruitment are to function as "the Right Man on The Right Place", where this is a guide for managers to place the workforce in the village office.

Recruitment is a series of activities to find and attract job applicants with the motivation, abilities, expertise and knowledge needed to cover the shortcomings identified in staff planning. While selection is the selection process of a group of applicants or people who meet the criteria for occupying available positions based on the conditions in the village office. Bicak village is one of the villages originating from the Trowulan Subdistrict, Mojokerto Regency, where the majority of the people earn their living farming, raising livestock, entrepreneurship and trading with community characters according to eastern customs, namely polite, ethical and religious. Reliable and competent human resources are leveraging factors for competitive advantage in the bicak village office, so the development of Human Resource Competence is one of the key success factors in achieving the vision and mission of the bicak village office. In line with the vision, mission, and office strategy to be a good village government and discipline, it is necessary to apply more focused efforts in developing HR consistently and continuously. Management of human resources is very necessary for the effectiveness of human resources in an organization. The aim of this is to provide the organization with an effective work unit to achieve the objectives of the study of village governance how companies should be able to develop, use and maintain devices in a fixed quality and quantity.

Therefore the village governance must be able to understand how best to manage employees who come from different backgrounds, expertise and abilities so that the device can work according to the expertise and type of work provided. Depreciation of employees that occurs usually due to employees entering retirement, dies. Therefore a new device that will replace it will have a different working period. Recruitment can also be done to add new devices to a work unit whose activities require high activity. In the recruitment process also requires the existence an effective selection process, this is done to make the device evenly distributed so that the strength of the owned HR becomes more balanced.

Failure to implement a labor recruitment system will have an impact on the process of achieving village objectives. Where the performance of bicak village 
Proceeding ICOGISS 2019

Page 221-231, ISBN: 978-602-6 988-75-1

Web Jurnal Online: jurnal.unmuhjember.ac.id

By: Santosa; Hikmah Muhaimin; Ahmad Hasan Afandi

Implementation of Selection and Recruitment on the Performance of Bicak Village Devices

in Trowualan District, Mojokerto Regency

equipment must be able to maintain continuity and provide good service for consumers. Given the very important process of recruitment and selection for the village. It is hoped that the existence of a good and effective recruitment and selection process will have an impact on the development of the village in the future to obtain quality resources in the bicak village office in Mojokerto District.

Based on the description above, the authors are interested in conducting research with the title: "Implementation of the Recruitment and Selection Process Against Employee Performance at the Bicak Village Office in Trowulan District".

\section{THEORETICAL FRAMEWORK}

\section{Recruitment}

Recruitment is one of the HRM functions in the aspect of procurement of labor specifically to get prospective employees to be selected which is the best and most in accordance with the required requirements, one of which is through the recruitment process. Human resources are employees, employees, laborers who work for an organization, company, government institution, educational institution, army, police, etc. who are recruited to carry out organizational management activities in achieving organizational goals. All of these are the main tasks and responsibilities of the HR department. The quality of a company's human resources depends on the quality of a recruitment process. According to (Hasibuan, 2007: 40). Recruitment as an effort to find and influence prospective workers to apply for jobs offered by a company. A similar definition was also put forward by (Nurmansyah, 2011: 71) which defines recruitment as an activity to get new workers to fill job vacancies in units within the company. The occurrence of job vacancies was caused by several things, namely (Nurmansyah, 2011: 71):

1. There are employees who are transferred

2. Stop on your own accord

3. Stop the company's decisions

4. Pension

5. Passed away

6. Expansion of business

7. Organizational adjustment

While (Simamora, 2005: 170) defines recruitment as a series of activities to find and attract job applicants with the motivation, ability, expertise, and knowledge needed to cover the shortcomings identified in personnel planning. The results of the recruitment are a group of job applicants who will then be selected as new employees in the company. Recruitment is essentially a process of determining and attracting applicants who are able to work in a company (Rivai \& Sagala, 2009: 148). The process begins when the applicant is sought, and ends when their application is submitted and accepted by the company. The result is a set of applicants for new candidates to be selected and selected. Besides recruitment can also be said as a process to get a number 
Proceeding ICOGISS 2019

Page 221-231, ISBN: 978-602-6 988-75-1

Web Jurnal Online: jurnal.unmuhjember.ac.id

By: Santosa; Hikmah Muhaimin; Ahmad Hasan Afandi

Implementation of Selection and Recruitment on the Performance of Bicak Village Devices in Trowualan District, Mojokerto Regency

of qualified human resources to occupy a position or job in a company. After HR planning is set, then it becomes the duty of the manager HR to think of several recruitment alternatives that can be carried out by companies with the most efficient costs. The need for this alternative is based on the consideration that recruitment requires high costs, including the interview research process, transfer of recruitment agency fees, and relocation problems, as well as the processing of new employees. Besides, the employees are processed in recruitment, then selected to be accepted as employees, later it will be difficult to be expelled (terminated), even though they show performance that low, because the employee has been protected by labor laws that regulate the rights and obligations of each party in the event of termination of employment (PHK). The cost of layoffs in Indonesia is not cheap, and is often a complaint of many foreign investors. Therefore, alternatives must be considered carefully and wisely before deciding on recruitment. The purpose of the recruitment is to accept as many applicants as possible according to the qualifications needed by the company from various applicant sources, so that it will enable netted candidates with the highest and best quality (Rivai \& Sagala, 2009: 150)

\section{Principles of Effective Recruitment}

Effective recruitment is very important now for several reasons. First,there is a dramatic change in which in some countries there is a phenomenon of a shortage of workers in accordance with the needs of the company. Second, some methods of recruitment are better than others, depending on the type of work. Third, the success of recruitment will depend on the extent of the problem area and recruitment policy (Dessler, 2011: 162).

According to (Rivai \& Sagala, 2009: 150-151) the principles that should be carried out in a recruitment process are as follows:

a. The quality of employees who must be recruited must be in accordance with the needs needed by the company so that it matches the position qualifications that will be filled, by analyzing the description and specification of the work.

b. The number of employees needed must be in accordance with the work available. To get this, it is necessary to forecast labor requirements and analyze labor requirements.

c. The required fees are minimal

d. Have planning and strategic decisions about recruitment.

e. Flexibility

f. Legal considerations

\section{Recruitment Objectives and Process}

The main objective of recruitment is to find qualified applicants who will remain with the company at the least cost (Simamora, 2005: 173). By Karen, applicants who are under qualified are predicted to be immediately dismissed in the middle of the road because they are unable to work as expected. While the over-qualified (excess qualifications) would be predicted to overtake themselves because they are not satisfied with the fulfillment that can be done by the company in screening the applicants. The safest thing is to find applicants who really match their qualifications. Recruitment can be done by identifying from various sources, including internal (from within the company) and external (from outside). 
Proceeding ICOGISS 2019

Page 221-231, ISBN: 978-602-6 988-75-1

Web Jurnal Online: jurnal.unmuhjember.ac.id

By: Santosa; Hikmah Muhaimin; Ahmad Hasan Afandi

Implementation of Selection and Recruitment on the Performance of Bicak Village Devices

in Trowualan District, Mojokerto Regency

\section{4. $\quad$ Factors Affecting Effective Recruitment}

It often happens in a job information, not many applicants are interested in submitting their application. Therefore, companies that must be sensitive to constraints that are effective. Factors commonly found in recruitment include:

1) Organizational characteristics: This affects the design and implementation of recruitment systems run by the company. For example, centralized organizations prefer to do a recruitment model based on cronyic closeness, or companies that do not have effective promotion and transfer patterns, would prefer to do recruitment patterns from outside the company.

2) The image of the organization of many applicants who are reluctant to apply in a particular company that has a negative image, on the contrary applicants will be in droves applying for company company applications that have a positive image, both in terms of employee welfare and excellence in their business fields.

3) Organizational policy: Organizational policy becomes a reference for managers to make decisions regarding recruitment. For example the employment status policy. Some companies that prefer to contract with new employees for a long period of time, are usually less favored by highly educated and experienced applicants.

4) Strategic plans and human resource plans Strategic plans show the direction of the company and determine the types of tasks and jobs that need to be carried out by human resources. Many companies prefer to recruit from internal companies for reasons of understanding and experience better than a completely new employee.

5) External conditions: Workers will influence the recruitment process. For example, in a surplus area (excess force work) so without making any job advertisements the company can already get many applicants.

6) Job requirements Applicants have the ability and interest in positions that are in accordance with their competencies. Therefore, it is important for the company to explain in detail what requirements are needed for the position offered

\section{Recruitment and Selection Process}

There are several recruitment and selection processes, including:

1) Perform work planning and application to assign tasks in a position to be filled.

2) Establish a candidate base for these positions by recruiting internal and external candidates.

3) Asking employees to fill out application forms and perhaps conduct screening interviews.

4) Utilizing various selection techniques such as tests, background investigations, physical tests to identify candidates who are eager to fill positions.

5) Ask candidates to take part in one or more selection interviews with supervisors and other relevant parties with the aim of finally assigning them to the candidate for which the position will be submitted.

In the recruitment process there are a number of factors that need special attention, including 31 :

1) Internal recruitment

2) If the vacant position is above the entry level, and employees who are capable of serving or doing a lot of work, recruitment from the internal organization should be done as a tool for career development and employee motivation and rewarding 
Proceeding ICOGISS 2019

Page 221-231, ISBN: 978-602-6 988-75-1

Web Jurnal Online: jurnal.unmuhjember.ac.id

By: Santosa; Hikmah Muhaimin; Ahmad Hasan Afandi

Implementation of Selection and Recruitment on the Performance of Bicak Village Devices in Trowualan District, Mojokerto Regency

good performance. With internal recruitment, employees are motivated to work hard to compete for higher positions and salaries.

3) Nepotism In recruiting nepotism is between family, chromium, friends of the party, fellow friends and friends of religion. A number of organizations have policies that prohibit recruiting employees based on nepotism. Even if an employee is going to marry another employee in the organization, one of them must stop working. Nepotism policy is aimed at avoiding unethical behavior, corrupt behavior and abuse of power in the organization.

\section{METHOD}

\section{Qualitative Research Methods}

Using Qualitative Research Methods. Because the problem is not clearly complex and dynamic so it is impossible for data in social situations to be explained by quantitative research methods with calls such as tests, questionnaires, and interviews. In addition, researchers also intend to understand social situations in depth.

Qualitative research is research on descriptive research and tends to use analysis. Process and meaning (subject perspective) are more highlighted in qualitative research. The theoretical foundation is used as a guide so that the focus of research is in accordance with the facts in the field. In addition, the theoretical basis is also useful to provide a general description of the background of the study and as a material for discussing the results of the study. There are fundamental differences between the role of theoretical foundation in quantitative research with qualitative research. In quantitative research, research departs from theory to data, and ends at the acceptance or rejection of the theory used; whereas in qualitative research researchers depart from the data, utilize existing theories as explanatory material, and end with a "theory".

Kriyantono stated that "qualitative research aims to explain the phenomenon as deeply as possible through deep data collection.". Qualitative research emphasizes the depth of data obtained by researchers. The deeper and detailed data obtained, the better the quality of this qualitative research. In contrast to quantitative, objects in qualitative research are generally limited in number. In this study, researchers participated in the events / conditions being studied. For this reason the results of this study require a depth of analysis from the researchers. In addition, the results of this study are subjective so that they cannot be generalized. In general, qualitative research is carried out by interview and observation methods. Through this method, the researcher will analyze the data obtained from the field in detail. Researchers cannot research social conditions that are dioservasi, because all reality that occurs is a natural unity. The results of qualitative research can also give rise to new theories or concepts if the results of their research conflict with the theories and concepts that were previously used as studies in research.

Qualitative research is far more subjective than quantitative research or surveys and uses methods very different from gathering information, especially individuals, in using in-depth interviews and focus groups. The nature of this type of research is that open research and exploration ends in relatively small groups interviewed in depth.

Participants are asked to answer general questions, and interviewers or moderators of research groups explore their responses to identify and determine 
Proceeding ICOGISS 2019

Page 221-231, ISBN: 978-602-6 988-75-1

Web Jurnal Online: jurnal.unmuhjember.ac.id

By: Santosa; Hikmah Muhaimin; Ahmad Hasan Afandi

Implementation of Selection and Recruitment on the Performance of Bicak Village Devices

in Trowualan District, Mojokerto Regency

perceptions, opinions and feelings about the ideas or topics discussed and to determine the degree of agreement in the group. The quality of the findings from qualitative research depends directly on the ability, experience and sensitivity of the group interviewer or moderator.

This type of research is often lacking in surveys because it is expensive and very effective in obtaining information about communication needs and responses and views about certain communications. In this case it is often the method of choice in cases where quantitative measurements or surveys are not needed.

- Data collection techniques

In qualitative research often used are purpose sampling and snowball sampling. As has been stated that purpose sampling is a technique of sampling data sources with certain considerations. This particular consideration, for example, the person who is considered to know the best about what we expect or maybe he is the ruler so that it will be easier for researchers to explore the object / social situation under study. Snowball sampling is a sampling technique of data sources that initially is a little over a large period of time. This is done because of the small number of data sources that have not been able to provide complete data, then looking for someone else that can be used as a data source. Thus the number of samples of data sources will be even greater, such as rolling snowballs that eventually become large.

-Data collection technique

The data collection technique is the most important step in the research, because the main purpose of the research is to obtain data that meets the established data standards. Data collection can be done in various settings. Various sources, and various ways. When viewed from the settings the data can be collected in natural settings in the laboratory using the experimental method, in schools with education and education personnel, at home with various respondents in a seminar, discussion, on the road and others. When viewed from the data source, then Data collection can use primary sources and secondary sources. Primary sources are data sources that directly provide data to data collectors, and secondary sources are sources that do not directly provide data to data collectors, for example through other people or through documents. Furthermore, when viewed in terms of methods or techniques of data collection can be done by observation, interviews, questionnaires, documentation and a combination of the four.

\section{DISCUSSION}

Bicak village is one of the villages originating from the Trowulan Subdistrict, Mojokerto Regency, where the majority of the people earn their living farming, raising livestock, entrepreneurship and trading with community characters according to eastern customs, namely polite, ethical and religious. The population continues to grow from year to year so it is a very densely populated area with varying levels of education ranging from elementary to tertiary education, the health level of the village of Bicak is quite good because it is supported by adequate facilities and infrastructure and sufficient public awareness high about the meaning of health. The distance from the village of Bicak to the capital city of Trowulan Subdistrict, which is relatively close, affects the 
Proceeding ICOGISS 2019

Page 221-231, ISBN: 978-602-6 988-75-1

Web Jurnal Online: jurnal.unmuhjember.ac.id

By: Santosa; Hikmah Muhaimin; Ahmad Hasan Afandi

Implementation of Selection and Recruitment on the Performance of Bicak Village Devices

in Trowualan District, Mojokerto Regency

pattern and behavior of the village community. In the past the village had formed a village bicak led by a village head who oversees 03 (three) hamlets / hamlets Namely:

1. Bicak Hamlet

2. Order Village

3. Hamlet

Each hamlet is led by a dukuh head or also called kepetengan and is now called the hamlet head assisted by RT, RW and other institutions. In return, the land is given to the rice field of Gajaran (crooked).

As for running the government, especially in terms of administration the village head / village head is assisted by carik and also carik helpers, or kebayan or now called kaur. From its inception until now the Bicak village has undergone several changes and several changes in village heads or village heads.

In some of these periods the community of Kertosari only used three kaur, namely the general vows, the forms of development and the welfare. But not with policies that now have to use five principles in accordance with the main tasks and functions. Namely financial and welfare measures On October 8, 2018 the office of the Kertosari village held a recruitment. (source from the village head and village secretary).

- The recruitment process

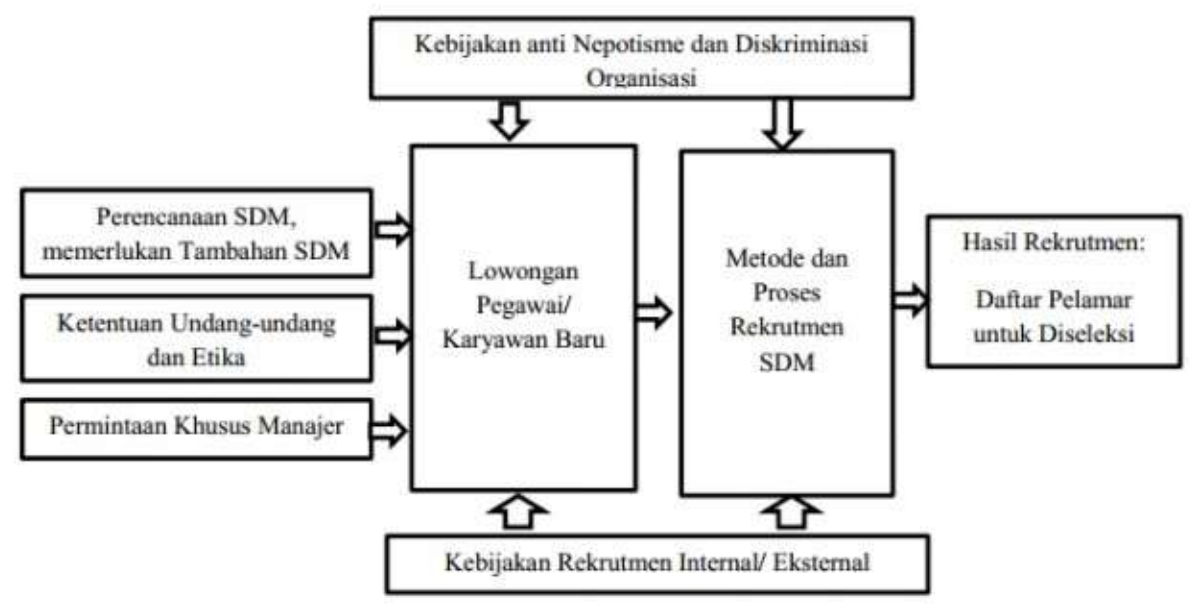

\section{Information:}

1) New employee / employee vacancies Employee vacancies are based on organizational HR planning that determines the need for new HR. The need for new human resources also considers the provisions of the labor law. For example, Article 8 of Law Number 13 of 2003 concerning Manpower regulates workforce planning prepared on the basis of employment information which includes:

a) Population and labor;

b) Job opportunities;

c) Job training including work competencies;

d) Labor productivity;

e) Industrial relations; 
Proceeding ICOGISS 2019

Page 221-231, ISBN: 978-602-6 988-75-1

Web Jurnal Online: jurnal.unmuhjember.ac.id

By: Santosa; Hikmah Muhaimin; Ahmad Hasan Afandi

Implementation of Selection and Recruitment on the Performance of Bicak Village Devices

in Trowualan District, Mojokerto Regency

f) Working environment conditions;

g) Wages and welfare of workers;

h) Social security of workers.

2) Recruitment

Recruitment also considers village / organization office anti-nepotism and discrimination policies and the organization's internal and external recruitment policies.

3) Company recruitment methods can use various recruitment techniques:

a) Advertisements in mass media: announcements of each village in each hamlet

b) the form can only be taken at the village hall

c) fulfill the requirements: SKCK and Good Conduct Letter

4) Recruitment results

The results of the selection are a number of application files submitted by the applicants in accordance with the requirements set by the rest of the village, those who have not fulfilled the requirements are declared not to qualify.

\section{Selection Process}

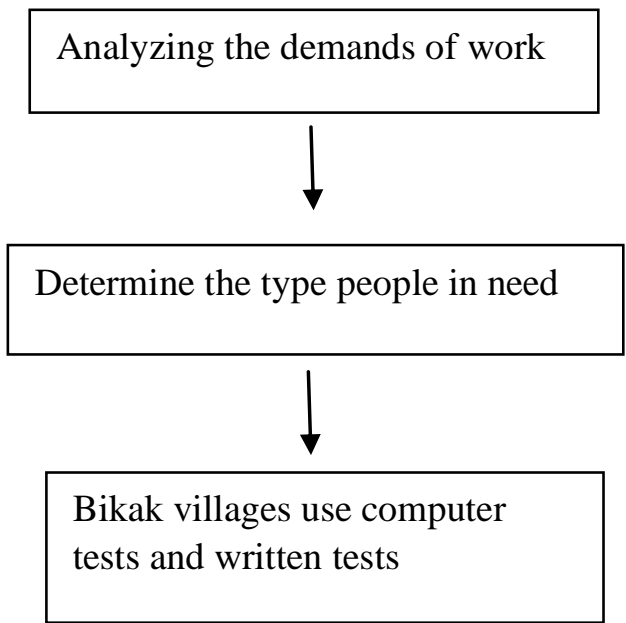

Information :

a. Analyzing the demands of work by using computer tests in the form of Microsoft Word and Microsoft Excel.

b. Determine the type people in need that concern intelligence by using written tests. From there the examiner can know how much knowledge and insight that the applicant has.

c. Bikak villages use computer tests and written tests. After passing the written test and getting the highest score, it can be stated that the applicant can become the village apparatus needed. 
Proceeding ICOGISS 2019

Page 221-231, ISBN: 978-602-6 988-75-1

Web Jurnal Online: jurnal.unmuhjember.ac.id

By: Santosa; Hikmah Muhaimin; Ahmad Hasan Afandi

Implementation of Selection and Recruitment on the Performance of Bicak Village Devices

in Trowualan District, Mojokerto Regency

From the recruitment and selection process in the village of Bicak, the district of Trowulan greatly influenced the performance of the device. Because with the recruitment of examiners, you can know how much you understand about computers and how much insight you have not only around the village but also the sub-district and other government. Its implementation with the recruitment of human resources can be filtered and get quality devices. now the village office has a financial position that can regulate expenses and can be proven through an accountability report. Whereas those who become welfare workers are also very cooperative and nimble in carrying out village tasks very disciplined.

\section{CONCLUSION}

1. The process of job recruitment, selection and training has a significant effect on the performance of bicak village officials in the Trowulan sub-district.

2. The partial recruitment process has a positive and significant effect on the performance of the bicak village equipment in the Trowulan sub-district.

3. Partial selection does not significantly affect the performance of the bicak village apparatus in the Trowulan sub-district.

4. Because with the recruitment of examiners, you can know how much you understand about the computer and how much insight you have not only around the village but also the sub-district and other government. Its implementation with the recruitment of human resources can be filtered and get quality devices. now the village office has financial means that can regulate expenses and can be proven through an accountability report. Whereas those who are welfare workers are also very cooperative and nimble in carrying out village tasks. Very disciplined.

\section{SUGGESTION}

It is hoped that for the village to improve employee performance, the company must pay more attention to the recruitment process because the better the recruitment process carried out by the village can improve employee performance, so the village government can get reliable and competent employees and based on the classification desired by the village community.

In this study the research is only limited to the influence and implementation of the process of recruitment, selection and job training on employee performance. While other factors that also affect the performance of employees that have not been revealed how much influence, hopefully in further research can discuss other factors that have not been studied in this study. 
Proceeding ICOGISS 2019

Page 221-231, ISBN: 978-602-6 988-75-1

Web Jurnal Online: jurnal.unmuhjember.ac.id

By: Santosa; Hikmah Muhaimin; Ahmad Hasan Afandi

Implementation of Selection and Recruitment on the Performance of Bicak Village Devices

in Trowualan District, Mojokerto Regency

\section{REFERENCES}

Rivai dan Ella Jauvani Sagala. 2009. Manajemen Sumber Daya Manusia Untuk Perusahaan. Grafindo Pustaka, Jakarta.

Sendow.P.A.\& Mekel. 2015. Pengaruh Perekrutan, Motivasi dan Pelatihan kerja terhadap Kinerja Pegawai pada PT.PLN (persero) wilayah suluttenggo. Jurnal EMBA Universitas Sam Ratulangi Manado. ISSN 2303-1174.

https://ejournal.unsrat.ac.id/index.php/emba/article/view/7929/7490. Diakses 09 september 2016.Hal. 1152- 1161.

Gary Dessler, Manajemen Sumber Daya Manusia. Jakarta: Prenhallindo, 1997, hal.127.

Ike Rachmawati, Manajemen Sumber Daya Manusia, Jakarta: PT Bumi Aksara, 2008, hal.91.

Veithzal Rivai, Manajemen Sumber Daya Manusia untuk Perusahaan, Jakarta: PT Raja GrafindoPersada, 2004, hal. 170. 